УДК 340.1

\title{
АКТУАЛЬНІ ПРОБЛЕМИ РЕАЛІЗАЦІЇ В УКРАЇНІ ЧЛЕНАМИ ПРОТЕСТАНТСЬКИХ ЦЕРКОВ ПРАВА НА АЛЬТЕРНАТИВНУ (НЕВІЙСЬКОВУ) СЛУЖБУ В ПЕРІОД МОБІЛІЗАЦЇ ТА ШЛЯХИ ЇХ ВИРІШЕННЯ
}

\author{
П. Циган \\ Львівський національний університет імені Івана Франка, \\ вул. Університетська, 1, Львів, Украӥна, 79000, \\ e-mail:qwertyupa@ukr.net
}

Розкрито сутність права на альтернативну (невійськову) службу. Охарактеризовано чинне законодавство України, яке закріплює право віруючих протестантських церков на проходження альтернативної (невійськової) служби в особливий період під час мобілізації. Проаналізовано судову практику щодо реалізації віруючими громадянами України права на альтернативну (невійськову) службу. Особливу увагу акцентовано на мотивах задоволення позовів членів протестантських церков до органів виконавчої влади в адміністративному судочинстві та постановлення виправдовувальних рішень щодо цієї категорії громадян у кримінальних провадженнях. Розглянуто окремі рішення судів України, за якими віруючим громадянам було відмовлено у забезпеченні вільного доступу до такої служби. Обґрунтовано наявність прогалин у законодавстві щодо використання віруючими громадянами України протестантських церков права на альтернативну (невійськову службу) в період мобілізації та запропоновано шляхи вирішення цієї проблематики.

Ключові слова: альтернативна (невійськова) служба, мобілізація, члени протестантських церков, закон, суд.

DOI: http://dx.doi.org/10.30970/vla.2020.70.039

Вступ. Основоположні права людини посідають важливе місце в усіх сферах суспільного життя. Особливого значення вони набувають у релігійній сфері, оскільки надають особі можливість вільно та безперешкодно сповідувати свою віру та захищати іiі від протиправних втручань та обмежень з боку органів державної влади. Практичне втілення прав людини у вищевказаній сфері сприяє гармонізації відносин між церквою та державою в Україні.

Постановка проблеми. Актуальність цієї теми вбачається в тому, що в Україні 32014 по 2016 роки, у період проведення шести хвиль часткової мобілізації, спостерігалася негативна тенденція порушення та обмеження прав на альтернативну (невійськову) службу осіб, виконання військового обов'язку яких суперечить їхнім релігійним переконанням. Порушення прав траплялися у формі відмов військових комісаріатів скеровувати віруючих протестантських конфесій на альтернативну (невійськову) службу і місцевих державних адміністрацій розглядати заяви, зазначених категорій громадян, щодо проходження ними такої служби.

Стан дослідження проблеми. Стосовно зазначеної проблеми в Україні $\epsilon$ обмаль наукових публікацій (зокрема - М. Васіна [7] і Д. Вовка) [4]. Певна інформація з цього питання міститься в публікаціях Інституту релігійної свободи та Української Гельсінської спілки з прав людини [7].

(C) Циган П., 2020 
Метою статті $\epsilon$ аналіз проблеми реалізації віруючими громадянами України, які сповідують протестантське віровчення права на альтернативну (невійськову) службу в період мобілізації

Виклад основного матеріалу. Право на альтернативну (невійськову) службу це право громадян, виконання військового обов'язку яких суперечить їхнім релігійним переконанням, на заміну військової служби іншою цивільною службою, яка має на меті виконання обов'язку перед суспільством. Це право може реалізувати особа, яка: 1) є громадянином України; 2) має релігійні переконання, які забороняють використання зброї; 3) є членом церкви, яка згідно зі законодавством України віднесена до релігійних організацій, віровчення яких не допускає користування зброєю.

Вказана проблематика регулюється як національним, так і міжнародним законодавством, зокрема: Конвенцією про захист прав та основоположних свобод, Конституцією України, Законом України «Про альтернативну (невійськову) службу», Законом України «Про мобілізаційну підготовку та мобілізацію», Постановою Кабінету Міністрів України «Про затвердження нормативно-правових актів щодо застосування Закону України «Про альтернативну (невійськову) службу».

Відповідно до ч. 2 ст. 9 Конвенції про захист прав та основоположних свобод «свобода сповідувати свою релігію або переконання підлягає лише таким обмеженням, що встановлені законом і $є$ необхідними в демократичному суспільстві в інтересах громадської безпеки, для охорони публічного порядку, здоров'я чи моралі або для захисту прав і свобод інших осіб»[5].

Згідно з ч. 4 ст. 35 Конституції України «ніхто не може бути увільнений від обов'язків перед державою або відмовитися від виконання законів за мотивами релігійних переконань. У разі, якщо виконання військового обов'язку суперечить релігійним переконанням громадянина, виконання цього обов'язку має бути замінене альтернативною (невійськовою) службою» [6].

Відповідно до ст. 2 Закону України «Про альтернативну (невійськову) службу» «право на альтернативну службу мають громадяни України, якщо виконання військового обов'язку суперечить їхнім релігійним переконанням і ці громадяни належать до діючих згідно з законодавством України релігійних організацій, віровчення яких не допускає користування зброєю». Частиною 2 ст. 9 цього Закону встановлено, «що у разі призову на військові збори громадян, які після проходження строкової військової служби набули релігійних переконань і належать до діючих згідно із законодавством України релігійних організацій, віровчення яких не допускає користування зброєю, вони не пізніше семи календарних днів від дня одержання повістки військового комісаріату про призов на військові збори подають особисто до відповідного структурного підрозділу місцевої державної адміністрації заяву про звільнення від призову на ці збори» [10].

Згідно 3 п. 11 ч. 1 ст. 23 Закону України «Про мобілізаційну підготовку та мобілізацію» «не підлягають призову на військову службу під час мобілізації інші військовозобов'язані або окремі категорії громадян у передбачених законами випадках» [12].

Постанова Кабінету Міністрів України «Про затвердження нормативно-правових актів щодо застосування Закону України «Про альтернативну (невійськову) службу» визначає перелік релігійних організацій, віровчення яких не допускає користування зброєю, до яких зокрема належать такі протестантські конфесії, як «Адвентисти-реформисти, Адвентисти сьомого дня, Свангельські християни, Свангельські християни-баптисти, Покутники, Свідки Єгови, Харизматичні християнські 
П. Циган

ISSN 0136-8168. Вісник Львівського університету. Серія юридична. 2020. Випуск 70

церкви (та церкви, прирівняні до них згідно із зареєстрованими статутами), Християни віри євангельської (та церкви, прирівняні до них згідно із зареєстрованими статутами), Християни євангельської віри» [11].

Усі наведені законодавчі положення щодо прав на альтернативну (невійськову) службу осіб, виконання військового обов'язку яких суперечить їхнім релігійним переконанням, саме в період мобілізації, далеко не завжди були втілені в життя. Судова практика в Україні свідчить про численні порушення військовими комісаріатами та місцевими державними адміністраціями права на таку службу. Як адміністративні суди (за позовами членів протестантських церков), так і суди загальної юрисдикції (у яких ці особи мали статус обвинувачених за невиконання військового обов'язку) підтримували правову позицію таких віруючих.

Щоб зрозуміти причини, суть порушень права на альтернативну (невійськову) службу віруючих громадян, які не можуть виконувати військового обов'язку за своїми релігійними переконаннями, а також мотиви ухвалення судами рішень, зазвичай на користь таких громадян, необхідно проаналізувати відповідну практику судів України. Наведемо окремі приклади судової практики з розглянутого питання.

У квітні 2015 року Рівненський окружний адміністративний суд розглядав позов члена євангельської церкви «Джерело життя» до Здолбунівської районної державної адміністрації Рівненської області, в якому вимагав визнати протиправним рішення державного органу про відмову у звільненні від військової служби у зв'язку з релігійними переконаннями, що унеможливлюють виконання військової служби. Районна державна адміністрація відмовляючи у клопотанні віруючої особи вказувала, що законодавством не передбачено надання звільнення від виконання військових обов'язків під час мобілізації на підставі релігійних переконань. Рівненський окружний адміністративний суд, задовольняючи позов члена Свангельської церкви «Джерело Життя» до Здолбунівської районної державної адміністрації Рівненської області про визнання протиправним рішення та зобов’язання вчинити певні дії, звернув увагу на те, що «...відсутність чіткого законодавчого врегулювання спірного питання, зокрема щодо внесення змін до Законів України “Про військовий обов'язок і військову службу”, “Про мобілізаційну підготовку та мобілізацію”, “Про альтернативну (невійськову) службу”, не може бути підставою для відмови віруючим громадянам, релігійні переконання яких не допускають користування зброєю, у проходженні альтернативної (невійськової) служби замість військового призову під час мобілізації. Судом також було зауважено, що аналіз чинного законодавства дає підстави для твердження, що військову службу під час мобілізації для віруючих громадян, які заявили про неможливість їі проходження 3 підстав суперечності їхнім релігійним переконанням, можна замінити на проходження альтернативної (невійськової) служби» [8].

Того ж року Харківським окружним адміністративним судом було розглянуто позов віруючої особи Свангельських християн до Фрунзенського районного військового комісаріату (далі - РВК) м. Харкова щодо визнання неправомірними дій відповідача стосовно призову позивача на військову службу під час мобілізації на особливий період. Військовий комісаріат відмовив особі у наданні права на альтернативну (невійськову) службу, зважаючи на те, що законом не визначено і не передбачено порядок направлення громадян на проходження цього виду служби саме під час мобілізації. Визнаючи неправомірними дії Фрунзенського РВК м. Харкова відносно віруючого Свангельської церкви, Харківський окружний адміністративний суд обгрунтовував право громадянина на альтернативну 
(невійськову) службу посиланням на норми Конвенції про захист прав людини й основоположних свобод.

Зокрема, вищеназваний орган вказував на те, що «Пункт статті 9 Свропейської конвенції з прав людини зазначає, що свобода сповідувати релігію або переконання підлягає лише таким обмеженням, які встановлені законом і є необхідними в демократичному суспільстві в інтересах громадської безпеки, для охорони громадського порядку, здоров'я чи моралі або для захисту прав і свобод інших людей. Перелік правомірних цілей, які виправдовують обмеження свободи віросповідання, передбачених ст. 9 Конвенції, є вичерпним. Відповідно ст. 9 не дозволяє посилатися на поняття «державної безпеки», щоб виправдати обмеження у здійсненні прав, що гарантуються, а «право на відмову від військової служби 3 релігійних переконань не може бути обмежено в інтересах національної безпеки та територіальної цілісності» [9].

У 2014 році в Новомосковському міськрайонному суді Дніпропетровської області перебувало на розгляді кримінальне провадження за фактом здійснення злочину членом релігійної громади «Свідки Сгови», передбаченого ст. 336 КК України - «Ухилення від призову за мобілізацією». Цю особу обвинувачували в тому, що після визнання військово-лікарською комісією його придатним для несення військової служби ним була подана заява про неможливість проходження будь-якої військової служби за релігійними переконаннями. Судом було ухвалено виправдовувальний вирок члену релігійної організації «Свідки Сгови» в кримінальному провадженні за ст. 336 КК України - «Ухилення від призову за мобілізацією». Новомосковський міськрайонний суд Дніпропетровської області мотивував своє рішення чинним законодавством України та практикою Свропейського суду 3 прав людини. Суд стверджував, що «... у відповідності з Положенням про порядок проходження альтернативної (невійськової) служби, затвердженого Постановою Кабінету Міністрів України № 2066 від 10.11.1999 року до переліку релігійних організацій, віровчення яких не допускає користування зброєю, належать, в тому числі Свідки Сгови. Згідно з довідкою № 2372 від 04.08.2014 року Центру Свідків Сгови релігійної організації «Релігійний центр Свідків Сгови в Україні» (а. п. 57) ОСОБА_2 з 10 липня 2004 року є присвяченим охрещеним служителем Релігійної організації Свідків Єгови в Україні. Отже, ОСОБА_2 підпадає під дію ч. 4 ст. 35 Конституції України, ч. 4 ст. 1 Закону України «Про військовий обов’язок і військову службу» та ст. 2 Закону України «Про альтернативну (невійськову) службу», а тому має право на заміну альтернативною службою військового обов'язку, в тому числі «військової служби за призовом під час мобілізації, оскільки належить до релігійної організації, віровчення якої не допускає користування зброєю...»[2].

Особливу увагу під час вирішення цієї справи Нововомосковський міськрайонний суд Дніпропетровської області звернув на практику Свропейського суду 3 прав людини (далі - ЄСПЛ), а саме на рішення «Баятян проти Вірменії», «Стефанов проти Болгарії», «Ерчєп проти Турції».

У рішенні по справі Баятян проти Вірменії» (скарга № 23459/03 від 07.07.2011 року) ЄСПЛ вказано, що (п. 110): «несприйняття військової служби коли мотивом такого несприйняття $€$ серйозний та нездоланний конфлікт між обов'язком служити в армії та переконанням конкретної особи або його глибокими та невдаваними релігійними чи іншими поглядами - $є$ переконанням або поглядом настільки незаперечним, серйозним, послідовним i значущим, що на нього поширюється гарантії статті 9 Європейської конвенції»; (п. 112): «неявка заявителя 
для проходження військової служби $\epsilon$ проявом його релігійних поглядів. У зв'язку 3 чим, притягнення його до кримінальної відповідальності за ухилення від призову $\epsilon$ втручанням у його свободу сповідувати свою релігію, гарантії якої передбачені п. 1 ст. 9 Європейської конвенції»; (п. 128): «Європейський Суд приходить до висновку, що притягнення заявителя до кримінальної відповідальності представляє собою втручання, яке не $є$ необхідним в демократичному суспільстві за змістом ст. 9 Європейської конвенції. Отже, мало місце порушення даної норми» [14].

У постанові суду (мировій угоді) в справі «Стефанов проти Болгарії» (скарга № 32438/96 від 03.05.2001 року) було акцентовано увагу на тому що (п. 14): «повинно бути припинено будь-яке кримінальне провадження, ініційоване в Болгарії з 1991 року стосовно громадян Болгарії, які відмовилися від військової служби на підставі переконань, але в той же час висловили готовність пройти альтернативну цивільну службу» $[15]$.

У рішенні «Ерчєп проти Турції» (скарга № 43965/04 від 22.11.2011 року), зазначено, що (п. 61): «заявитель, будучи Свідком Сгови, намагався отримати звільнення від військової служби не задля своєї вигоди чи зручності, а у зв'язку зі своїми невдаваними релігійними переконаннями. Свропейський суд також відзначив, що заявитель ніколи не відмовлявся від виконання своїх громадянських обов'язків в цілому, а навпаки, відкрито просив власті надати йому можливість пройти альтернативну цивільну службу...» [16].

Варто вказати, що судова практика не завжди іде в напрямі забезпечення права особи на альтернативну (невійськову) службу під час мобілізації. На цей час $є$ окремі вироки судів, які застосовували до віруючих протестантських церков, які відмовлялися проходити військову службу в період мобілізації на підставі релігійних переконань, санкції кримінально-правового характеру.

Одним із таких негативних прикладів є вирок Володимирецького районного суду в справі № 556/127/15-к, за яким віруючого церкви Християн Віри Свангельської (далі - ХВС), який повідомив про неможливість проходження військової служби на підставі своїх релігійних переконань, було притягнуто до кримінальної відповідальності. При цьому суддя у тексті вироку посилався на те, що «...обвинувачений не надав суду доказів того, що член церкви XВС не може брати до рук зброю та захищати Батьківщину». Заступник військового комісара Володимирецького ОРВК з мобілізації повідомив у судовому засіданні, «що він не вповноважений займатися поверненням додому членів XВС та інших “сектантів”, оскільки це здійснює обласний військовий комісаріат» [1].

Необхідно наголосити, що вказана справа мала своє продовження в Апеляційному суді Рівненської області. 28 травня 2015 року вказаним органом було залишено без змін вирок Володимирецького районного суду Рівненської області, а апеляційну скаргу обвинуваченого без задоволення. Відмовляючи у задоволенні апеляційної скарги віруючого судом було зауважено, що: «... при апеляційному розгляді справи стороною захисту не було надано суду даних щодо виконання обвинуваченим вимог ч. 2 ст. 9 Закону "Про альтернативну (невійськову) службу", якою передбачено, що у разі призову громадян, які після проходження строкової військової служби набули релігійних переконань і належать до діючих згідно із законодавством України релігійних організацій, віровчення яких не допускає користування зброєю, подають особисто до відповідного структурного підрозділу місцевої державної адміністрації заяву про звільнення від призову на ці збори. За таких обставин апеляційний суд вважає позбавленими підстав доводи щодо неможливості мобілізації обвинуваченого в силу його релігійних переконань» [17]. 
При оцінці цього судового рішення варто погодитись із позицією, яку висловив юрист, виконавчий директор Інституту релігійної свободи Максим Васін, що ч. 2 ст. 9 Закону «Про альтернативну (невійськову) службу» стосується не випадків мобілізації на військову службу, а порядку звільнення віруючих громадян від призову на навчальні військові збори. Тому її застосування за аналогією допустиме лише у якості підстави для забезпечення конституційного права громадян, а не як обов'язок, недотримання якого спричинює кримінальне покарання. Адже в такому випадку цю норму не можна вважати достатньо чіткою та однозначною, яка б дозволяла передбачити конкретні наслідки ії порушення. Тому недотримання цієї норми не може бути підставою для кримінального покарання [7].

Причинами порушення прав віруючих осіб на альтернативну (невійськову службу) $є$ неправильне застосування законодавства уповноваженими органами i відсутність конкретної норми в Законі України «Про альтернативну (невійськову) службу» щодо поширення положень вказаного законодавчого акту на випадки проходження військової служби в особливий період під час мобілізації.

Варто відзначити, що вирішенням аналізованої проблематики займався Комітет з національної безпеки та оборони Верховної Ради України (далі - ВРУ) восьмого скликання. Так, 21 квітня 2016 року у цьому органі було зареєстровано проект закону «Про внесення змін до Закону України «Про альтернативну (невійськову) службу (щодо строків подання заяви)» № 4485. Окремі його положення були спрямовані на розширення сфери дії Закону України «Про альтернативну (невійськову) службу» на усі випадки проходження військової служби, а не лише щодо проходження строкової військової служби, шляхом внесення змін у статті 1 і 4 цього нормативно-правового акту.

Зокрема, автори законопроекту запропонували у частині першій ст. 1 та частині першій ст. 4 слово «строкової» вилучити. Усунення вказаного слова суттєво впливало на зміст зазначеної норми закону. У чинній редакції ч. 1 ст. 1 Закону України «Про альтернативну (невійськову) службу» передбачено, що «альтернативна служба є службою, яка запроваджується замість проходження строкової військової служби і має на меті виконання обов'язку перед суспільством» [10]. Згідно зі законопроектом № 4485 вказано, що «альтернативна служба є службою, яка запроваджується замість проходження військової служби і має на меті виконання обов'язку перед суспільством» [13]. Згідно з ч. 1 ст. 4 Закону України «Про альтернативну (невійськову) службу», чинною нині, «на альтернативну службу направляються громадяни, які підлягають призову на строкову військову службу і особисто заявили про неможливість ііі проходження як такої, що суперечить їхнім релігійним переконанням, документально або іншим чином підтвердили істинність переконань та стосовно яких прийнято відповідні рішення» [10]. У наведеному законопроекті зазначено, що «на альтернативну службу направляються громадяни, які підлягають призову на військову службу і особисто заявили про неможливість ії проходження як такої, що суперечить їхнім релігійним переконанням, документально або іншим чином підтвердили істинність переконань та стосовно яких прийнято відповідні рішення» [13].

Пропозиції щодо вдосконалення окремих положень закону є цілком слушними, оскільки поточна редакція ч. 1 ст. 1 і ч. 1 ст. 4 є досить вузькою і містить невизначеність щодо питання можливості реалізації права на альтернативну (невійськову) службу віруючими громадянами протестантських церков під час мобілізації, внаслідок чого набуває поширення негативна тенденція створення перешкод для вищенаведеної категорії осіб у використанні цього права. Фактичне 
П. Циган

ISSN 0136-8168. Вісник Львівського університету. Серія юридична. 2020. Випуск 70

втілення норм проекту закону № 4485 сприятиме повноцінній та вільній реалізації, членами ключових протестантських церков (євангельських християн - баптистів, п’ятидесятників, адвентистів), права на проходження альтернативної (невійськової) служби, незалежно від виду військової служби.

Однак, проект закону № 4485 згідно з висновком Головного науково-експертного управління ВРУ від 30 травня 2016 року був відправлений на доопрацювання, зважаючи на те, що законопроектні зміни є фрагментарними і лише частково вирішують проблеми, пов'язані з альтернативною службою. Деякі із пропонованих змін не узгоджується з іншими законодавчими актами, а їх зміст не відповідає предмету регулювання статті, до якої їх вносять. Зауваження також стосувалися приведення положень законопроекту у відповідність до правил законотворчої техніки [4]. Невдовзі 29 серпня 2019 року він взагалі був знятий з розгляду Комітету.

Також доцільно для повноцінної реалізації права віруючими особами на альтернативну (невійськову) службу розширити перелік релігійних організацій, віровчення яких не допускає користування зброєю, затверджений Постановою Міністрів України «Про затвердження нормативно-правових актів щодо застосування Закону України “Про альтернативну (невійськову) службу”», оскільки цей порядок не переглядали 3 моменту прийняття 1999 року, а за 20 років в Україні з'явилося більше десятка тисяч новітніх віровчень протестантських релігійних громад [7].

Висновки. На цей час законодавством України належно закріплено лише порядок скерування громадян на строкову військову службу та військові збори. Питання щодо проходження альтернативної (невійськової) служби віруючими особами, саме за мобілізацією, не $є$ належно врегульованим чинним законодавством. Реалізація права на альтернативну (невійськову) службу регулює ч. 4 ст. 35 Конституції України і ст. 2 Закону України «Про альтернативну (невійськову) службу» лише в загальних рисах, при цьому є відсутніми конкретні законодавчі положення, які би визначали порядок проходження цього виду служби в зазначений час. Наявність законодавчої прогалини у цьому питанні $\epsilon$ причиною низки порушень названого права 3 боку державних органів. У більшості спорів між членами протестантських церков і органами державної влади суди зазвичай підтримували позицію перших, звертаючи увагу на те, що «...відсутність чіткого законодавчого врегулювання спірного питання, а саме щодо внесення змін до Законів України "Про військовий обов'язок і військову службу”, “Про мобілізаційну підготовку та мобілізацію”, "Про альтернативну (невійськову) службу”, не може бути підставою для відмови віруючим громадянам, релігійні переконання яких не допускають користування зброєю, у проходженні альтернативної (невійськової) служби замість військового призову під час мобілізації» [8].

Юридична наука та судова практика сформулювали теоретичну та прикладну основи для законопроекту № 4485, з урахуванням усіх зауважень та пропозицій, висловлених Головним науково-експертним управлінням ВРУ для заповнення наявної прогалини.

\section{Список використаних джерел}

1. Вирок Володимирецького районного суду Рівненської області від 13.03.2015 р. у кримінальний справі № 556/127/15-к // Єдиний державний реєстр судових рішень. URL: http://www.reyestr.court.gov.ua/Review/43079332.

2. Вирок Новомосковського міськрайонного суду Дніпропетровської області від 13.11.2014 p. у справі № 183/6316/14 // Єдиний державний реєстр судових рішень. URL: http://www.reyestr.court.gov.ua/Review/41351969. 
3. Висновок Головного науково-експертного управління 30.05.2016. URL: http://w1.c1.rada.gov.ua/pls/zweb2/webproc34?id=\&pf3511=58817\&pf35401=389711.

4. Вовк Д. О. Як українські суди балансують релігійну свободу: аналіз у контексті світськості. // Право і громадянське суспільство: електрон. вид. 2014. № 3. С. 4-37. URL: http://lcslaw.knu.ua/2014-3.pdf.

5. Конвенція про захист прав та основоположних свобод: міжнародний документ від 17.07.1997. URL: https://zakon.rada.gov.ua/go/995_004.

6. Конституція України [Текст]: офіц. текст: [прийнята на п'ятій сесії Верховної Ради України 28 червня 1996 р. із змінами, внесеними Законом України від 8 грудня 2004 р.: станом на 1 січня 2006 р.]. Київ: Мін-во Юстиції України, 2006. 124 с.

7. Максим Васін. Альтернативна (невійськова) служба: шлях реформ або вироків?. // Інститут релігійної свободи. 2015. URL: https://irs.in.ua/ua/2015-maksym-vasin-onalternative-non-military-service-in-ukraine.

8. Постанова Рівненського окружного адміністративного суду 14 квітня 2015 року у справі № 817/818/15. // Єдиний державний реєстр судових рішень. URL: http://www.reyestr.court.gov.ua/Review/43710494.

9. Постанова Харківського окружного адміністративного суду 11 червня 2015 року у справі № 820/5487/15 // Єдиний державний реєстр судових рішень. URL: http://www.reyestr.court.gov.ua/Review/45105474.

10. Про альтернативну (невійськову) службу: Закон України від 12 грудня 1991 р. № 15 // Відомості Верховної Ради України (ВВР). 1992. № 15. С. 188. URL: http://zakon4.rada.gov.ua/laws/show/1975-12.

11. Про затвердження нормативно-правових актів щодо застосування Закону України "Про альтернативну (невійськову) службу": Постанова Кабінету Міністрів України від 10 листопада 1999 р № 2066. URL: https://zakon.rada.gov.ua/go/2066-99-п.

12. Про мобілізаційну підготовку та мобілізацію: Закон України від 21 жовтня 1993 р № 3543-XII // Відомості Верховної Ради України (ВВР). 1993. № 44. С. 416. URL: https://zakon.rada.gov.ua/go/3543-12.

13. Про внесення змін до Закону України "Про альтернативну (невійськову) службу" (щодо строків подання заяви): Проект Закону від 21.04.2016 2679-VIII. URL: http://w1.c1.rada.gov.ua/pls/zweb2/webproc34?id=\&pf3511=58817\&pf35401=385188.

14. Рішення Європейського суду з прав людини у справі «Баятин проти Вірменії». URL: http://europeancourt.ru/resheniya-evropejskogo-suda-na-russkom-yazyke/bayatyan-protivarmenii-postanovlenie-bolshoj-palaty-evropejskogo-suda/.

15. Рішення Європейського суду з прав людини у справі «Стефанов проти Болгарії». URL: http://europeancourt.ru/resheniya-evropejskogo-suda-na-russkom-yazyke/stefanov-protivbolgarii-postanovlenie-evropejskogo-suda/.

16. Рішення Європейського суду з прав людини у справі «Ерчєп проти Турції». URL: https://jurliga.ligazakon.net/news/134061_veruyushchie-mobilizovannye-imeyut-pravo-naalternativnuyu-sluzhbu---vssu.

17. Ухвала Апеляційного суду Рівненської області від 28.05.2015 року по кримінальному провадженню за № 12014180050000848. URL: http://www.reyestr.court.gov.ua/Review/44605099.

\section{References}

1. Vyrok Volodymyrets'koho rajonnoho sudu Rivnens'koi oblasti vid 13.03.2015 r. u kryminal'nyj spravi № 556/127/15-k. Yedynyj derzhavnyj reiestr sudovykh rishen'. Retrieved from http://www.reyestr.court.gov.ua/Review/43079332. 
2. Vyrok Novomoskovs'koho mis'krajonnoho sudu Dnipropetrovs'koi oblasti vid 13.11.2014r. u spravi № 183/6316/14. Yedynyj derzhavnyj reiestr sudovykh rishen'. Retrieved from http://www.reyestr.court.gov.ua/Review/41351969.

3. Vysnovok Holovnoho naukovo-ekspertnoho upravlinnia 30.05.2016. Retrieved from http://w1.c1.rada.gov.ua/pls/zweb2/webproc34?id=\&pf3511=58817\&pf35401=389711.

4. Vovk, D. (2014). Yak ukrains'ki sudy balansuiut' relihijnu svobodu: analiz u konteksti svits'kosti. Pravo i hromadians'ke suspil'stvo : elektron. vyd., № 3, 4-37. Retrieved from http://lcslaw.knu.ua/2014-3.pdf (accessed: 01/13/2016).

5. Constitution of Ukraine (2006). [Text]: Off. text: [adopted at the Fifth Session of the Verkhovna Rada of Ukraine on June 28, 1996, as amended by the Law of Ukraine of December 8, 2004: as of January 1, 2006]. Kyiv: Ministry of Justice of Ukraine.

6. Vasin, M. (2015). Al'ternatyvna (nevijs'kova) sluzhba: shliakh reform abo vyrokiv? Retrieved from https://irs.in.ua/en/2015-maksym-vasin-on-alternative-non-military-service-in-ukraine.

7. Konventsiia pro zakhyst prav ta osnovopolozhnykh svobod: mizhnarodnyj dokument vid 17.07.1997. Retrieved fromhttps://zakon.rada.gov.ua/go/995_004.

8. Postanova Rivnens'koho okruzhnoho administratyvnoho sudu 14 kvitnia 2015 roku u spravi 817/818/15. Yedynyj derzhavnyj reiestr sudovykh rishen'. Retrieved from http://www.reyestr.court.gov.ua/Review/43710494.

9. Postanova Kharkivs'koho okruzhnoho administratyvnoho sudu 11 chervnia 2015 roku u spravi $N$ 820/5487/15. Yedynyj derzhavnyj reiestr sudovykh rishen'. Retrieved from http://www.reyestr.court.gov.ua/Review/45105474

10. Pro al'ternatyvnu (nevijs'kovu) sluzhbu: Zakon Ukrainy vid 12 hrudnia 1991 N15. Vidomosti Verkhovnoi Rady Ukrainy. Retrieved from http://zakon4.rada.gov.ua/laws/show/1975-12.

11. Pro zatverdzhennia normatyvno-pravovykh aktiv schodo zastosuvannia Zakonu Ukrainy «Pro al'ternatyvnu (nevijs'kovu) sluzhbu: Postanova Kabinetu Ministriv Ukrainy vid 10 lystopada 1999r № 2066. Retrieved from https://zakon.rada.gov.ua/go/2066-99-p.

12. Pro mobilizatsijnu pidhotovku ta mobilizatsiiu: Zakon Ukrainy vid 21 zhovtnia $1993 \mathrm{r}$ № 3543-XII. Vidomosti Verkhovnoi Rady Ukrainy. Retrieved from https://zakon.rada.gov.ua/go/3543-12.

13. Pro vnesennia zmin do Zakonu Ukrainy "Pro al'ternatyvnu (nevijs'kovu) sluzhbu" (schodo strokiv podannia zaiavy): Proekt Zakonu vid 21.04.2016 2679-VIII. Retrieved fromhttp://w1.c1.rada.gov.ua/pls/zweb2/webproc34?id=\&pf3511=58817\&pf35401=385188.

14. Rishennia Yevropejs'koho sudu z prav liudyny u spravi "Baiatyn proty Virmenii”. Retrieved from http://europeancourt.ru/resheniya-evropejskogo-suda-na-russkom-yazyke/bayatyanprotiv-armenii-postanovlenie-bolshoj-palaty-evropejskogo-suda/.

15. Rishennia Yevropejs'koho sudu z prav liudyny u spravi "Stefanov proty Bolharii”. Retrieved from http://europeancourt.ru/resheniya-evropejskogo-suda-na-russkom-yazyke/stefanov-protiv-bolgarii-postanovlenie-evropejskogo-suda/.

16. Rishennia Yevropejs'koho sudu z prav liudyny u spravi "Erchiep proty Turtsii”. Retrieved from https://jurliga.ligazakon.net/news/134061_veruyushchie-mobilizovannye-imeyut-pravona-alternativnuyu-sluzhbu---vssu.

17. Ukhvala Apeliatsijnoho sudu Rivnens'koi oblasti vid 28.05.2015 roku po kryminal'nomu provadzhenniu za № 12014180050000848. Yedynyj derzhavnyj reiestr sudovykh rishen'. Retrieved from http://www.reyestr.court.gov.ua/Review/44605099. 


\title{
CURRENT ISSUES OF REALIZATION OF THE RIGHT TO ALTERNATIVE (NON-MILITARY) SERVICE IN UKRAINE BY MEMBERS OF THE PROTESTANT CHURCHES DURING THE MOBILIZATION PERIOD AND WAYS OF THEIR SOLUTION
}

\author{
P. Tsyhan \\ Ivan Franko National University of Lviv, \\ 1, Universytetska Str., Lviv, Ukraine, 79000, \\ e-mail:qwertyupa@ukr.net
}

The right to alternative (non-military) service is the right of citizens whose military duty contradicts their religious beliefs to replace military service with another civilian service intended to fulfill their duty to society.

For 2014-2016 years, during the period of partial mobilization, there had been a negative tendency to restrict the right to alternative (non-military) service towards members of the Protestant churches by the military commissariats and local state administrations.

The believing citizens of Ukraine who profess the Protestant doctrine actively defended their right to pass alternative (non-military) service during the mobilization period by appealing to court. In the claims to local state administrations and military commissariats, this category of citizens of Ukraine demanded to declare actions of such authorities illegal and to oblige the latter to provide the plaintiffs with alternative (non-military) service.

In most cases of public law disputes over the claims of members of the Protestant churches as well as in the criminal proceedings, where the mentioned citizens of Ukraine had the status of "defendants", both courts of general jurisdiction and district administrative courts took the position of such believers. In deciding in favor of the aforementioned persons, the courts justified the right of the believing citizens of Ukraine to alternative (non-military) service in the period of mobilization by the provisions of Part 5 of Art. 35 of the Constitution of Ukraine, Art. 9 of the European Convention on Human Rights and the case-law of the European Court of Human Rights.

It is worth noting that the case-law not of all courts of Ukraine goes in line with ensuring the right of the person to alternative (non-military) service. Thus, the Volodymyretsky District Court and the Appeal Court of Rivne region, considering the criminal proceedings under Article 335 of the Criminal Code of Ukraine "Evasion from mobilization call" against a member of the Church of the Christians of the Evangelical Faith who gave up military service because of the religious beliefs, pointed out that "the defendant failed to provide the court with evidence that a member of the HVE Church cannot take up arms and protect the Motherland'.

The reasons for violating the rights of the believers to alternative (non-military) service are the incorrect application of the legislation by the authorized bodies and the absence of a specific rule in the Law of Ukraine "On Alternative (Non-Military) Service" regarding the extension of the provisions of the said legislative act to cases of military service during a special period.

In order to eliminate the gaps in the Law, it is necessary to re-register in the Supreme Rada of Ukraine the Draft Law "On Amendments to the Law of Ukraine" On Alternative (NonMilitary) Service No. 4485 (concerning the terms of filing an application), which contains a provision for extending its scope to all cases of passing a citizen of military service, not limited to the state of emergency.

Keywords: alternative (non-military) service, mobilization, members of Protestant churches, law, court. 